\title{
PENGARUH EDUKASI GIZI BERBASIS VIDEO TERHADAP PENINGKATAN PENGETAHUAN REMAJA PUTRI DI JAKARTA TIMUR
}

\author{
Haniyyah Prastia Putri ${ }^{1}$, Fathiya Andara ${ }^{1}$ dan Dian Luthfiana Sufyan ${ }^{1}$
} ${ }^{1}$ Program Studi Gizi, Fakultas Ilmu Kesehatan, Universitas Pembangunan Nasional Veteran Jakarta
Email: haniyyahprastiaputri@upnvj.ac.id

\begin{abstract}
Compared to adolescent boys, adolescent girls have a higher risk of developing anemia. The need for iron absorption reaches its peak at the age of 14-15 years in adolescent girls. Anemia is a condition which the number of red blood cells is insufficient to meet the physiological needs of the body. The national prevalence of anemia in adolescent girls in Indonesia according to Riskesdas is $21.7 \%$, this shows that anemia in adolescent girls is still a problem because the prevalence rate is still high. Anemia in adolescent girls can have adverse effects such as decreased reproductive health, motor and mental development, intelligence, learning achievement, fitness levels, and not achieving maximum height. Lack of knowledge can be a factor in the problem of anemia in adolescent girls. Several ways can be done to increase the knowledge and attitudes of adolescent girls, one of which is by providing nutrition education about balanced nutrition guidelines, clean and healthy living behavior, and knowledge about anemia with video-based as a tool. The purpose of the study was to determine the effect of video-based nutrition education on the level of knowledge of adolescent girls aged 15-21 years in the East Jakarta area. The level of knowledge was measured using a pre test before being given education and a post test after being given video-based education. The analysis used to process the data used statistical paired $t$-test. The results of the activity show that there is an effect of providing video-based nutrition education on the knowledge of adolescent girls aged 15-21 years in the East Jakarta area which is supported by a p-value $<0.05$.
\end{abstract}

Keywords: Anemia, Nutrition Education, Video, Adolescent Girls

\begin{abstract}
ABSTRAK
Dibandingkan dengan remaja putra, remaja putri memiliki risiko tinggi mengalami anemia. Kebutuhan penyerapan zat besi pada remaja putri mencapai punjaknya pada usia 14-15 tahun pada remaja putri. Anemia adalah suatu keadaan dimana jumlah sel darah merah tidak mencukupi untuk memenuhi kebutuhan fisiologis tubuh. Prevalensi nasional anemia pada remaja putri di Indonesia menurut Riskesdas adalah 21,7\%, hal ini menunjukkan bahwa anemia pada remaja putri masih menjadi masalah kesehatan karena angka prevalensinya masih tinggi. Dampak tidak baik akibat dari anemia pada remaja diantaranya menurunnya perkembangan motorik, mental, menurunnya kesehatan pada reproduksi, perkembangan motorik, kecerdasan, prestasi belajar, tingkat kebugaran dan tinggi badan tidak mencapai maksimal. Kurangnya pengetahuan dapat menjadi salah satu faktor permasalahan terjadinya anemia pada remaja putri. Beberapa cara dapat dilakukan untuk dapat meningkatkan pengetahuan dan sikap remaja putri, salah satunya adalah dengan pemberian edukasi gizi mengenai pedoman gizi seimbang, perilaku hidup bersih dan sehat, dan pengetahuan tentang anemia berbasis video sebagai alat bantu. Tujuan kegiatan dilakukan untuk mengetahui pengaruh edukasi gizi berbasis video terhadap tingkat pengetahuan remaja putri berusia 15-21 tahun di wilayah Jakarta Timur. Tingkat pengetahuan diukur menggunakan pre test sebelum diberikan edukasi dan post test setelah diberikan edukasi berbasis video. Analisis yang digunakan untuk mengolah data menggunakan uji statistik paired t-test. Hasil kegiatan menunjukkan bahwa terdapat pengaruh pemberian edukasi gizi berbasis video terhadap pengetahuan remaja putri berusia 15-21 tahun di wilayah Jakarta Timur yang didukung dengan p-value <0,05.
\end{abstract}

Kata Kunci: Anemia, Edukasi Gizi, Video, Remaja Putri

\section{PENDAHULUAN}

Anemia memiliki risiko yang lebih tinggi pada remaja putri dibandingkan pada remaja putra dimana kebutuhan absorpsi zat besi pada remaja putri yang mengalami puncaknya pada umur 1415 tahun, sedangkan satu atau dua tahun berikutnya pada remaja putra (World Health Organization, 2011). Remaja masuk dalam kategori Wanita Usia Subur (WUS). WUS merupakan wanita yang masuk dalam usia reproduktif antara usia 15-49 tahun, yaitu dimana munculnya haid pertama sampai berhentinya haid, masih memiliki potensi untuk mempunyai keturunan, dengan status belum menikah, menikah, atau janda. WUS membutuhkan perhatian yang khusus dalam mempersipakna kehamilan karena erat kaitannya dengan kelahiran. Adanya masalah gizi ganda 
(double burden malnutrition) yang beragam dan juga kompleks dimana persoalan Kurang Energi Kronis (KEK) dan anemia diikuti dengan peningkatan prevalensi obesitas belum terselesaikan dengan baik pada WUS, kualitas diet dan gaya hidup yang buruk pada WUS menjadi penyebab utama (Nurramadhani et al., 2019).

Anemia ditandai dengan kadar Hemoglobin pada plasma yang lebih rendah daripada nilai normal untuk kategori inidividu berdasarkan jenis kelamin dan usia. Kadar hemoglobin normal pada remaja putri yaitu $12-15 \mathrm{~g} / \mathrm{dl}$, sedangkan remaja putra yaitu $13-17 \mathrm{~g} / \mathrm{dl}$. Berdasarkan WHO anemia adalah kondisi jumlah dari eritrosit yang tidak cukup dalam pemenuhan kebutuhan fisiologis tubuh dan beragam berdasarkan jenis kelamin, usia, tahap kehamilan, daerah tinggal, dan perilaku merokok. Anemia disebabkan oleh beberapa hal, antara lain intake makanan yang tidak memenuhi kebutuhan, tereliminasinya eritrosit akibat trauma, pendarahan yang parah , menstruasi, infeksi, dan penurunan atau pembentukan sel yang abnormal(Indrastata, 2019). Kekurangan zat besi juga dapat menyebabkan anemia pada remaja putri. Kegunaan dari zat besi yaitu pembentukan eritrosit, sehingga jika tubuh kekurangan zat besi mengakibatkan gangguan dalam pembentukan eritrosit dan dapat menyebabkan anemia (Harahap, 2018).

Remaja putri merupakan salah satu kelompok yang rawan mengalami anemia. Prevalensi anemia pada remaja berdasarkan data Riskesdas 2018 yaitu sebesar 32\%, yang memiliki arti 3-4 dari 10 remaja mengalami anemia. Prevalensi pada wanita lebih besar yaitu 27,2\% dibandingkan pria yaitu 20,3\% (Badan Penelitian dan Pengembangan Kesehatan, 2018). Berdasarkan penelitian yang telah dilakukan sebelumnya, didapatkan bahwa 5 wilayah di Jakarta memiliki prevalensi anemia pada remaja putri sebesar 44,6\% (Junengsih \& Yuliasari, 2017).

Dampak tidak baik akibat dari anemia pada remaja diantaranya menurunnya perkembangan motorik, mental, menurunnya kesehatan pada reproduksi, perkembangan motorik, kecerdasan, prestasi belajar, tingkat kebugaran dan tinggi badan tidak mencapai maksimal. (Harahap, 2018). Dampak langsung pada remaja putri yang terkena anemia adalah mata berkunang-kunang dan sering mengeluh pusing, kulit, lidah, bibir, kelopak mata dan telapak tangan terlihat pucat, terlihat letih, lemahh, lesu, lelah, dan lunglai dan dapat menimbulkan dampak jangka panjang pada generasi yang akan datang karena perempuan akan mengalami kehamilan dan memiliki anak, remaja yang mengalami anemia dapat lebih parah pada saat kehamilan karena di masa tersebut membutukan zat besi yang lebih dan jika tidak ditangani akan berdampak negatif pada janin dan sang ibu(Apriyanti, 2019).

Salah satu faktor anemia karena terjadinya pendarahan pada remaja putri. Pendarahan dapat terjadi karena kecelakaan atau haid yang berlebihan (haid $>6$ hari). Pada masa pubertas, dibutuhkan asupan zat gizi untuk memenuhi kebutuhan remaja putri. Kurangnya asupan gizi pada remaja putri khususnya zat besi dapat menyebabkan anemia. Remaja putri disarankan mengonsumsi sumber protein hewani, seperti ikan, ayam, dan daging. Sumber protein lainnya ialah telur, sayuran hijau,buah, serealia, dan kacang-kacangan. Hal yang patit diperhatikan yaitu jumlah zat besi, kualitas zat besi dalam pangan dan juga ketersediaan biologisnya (Sukarni \& Wahyu, 2013).

Berdasarkan tingginya risiko gangguan gizi pada remaja putri seperti anemia, pemerintah mengeluarkan Peraturan Menteri Kesehatan RI Nomor 41 Tahun 2014 tentang Pedoman Gizi Seimbang (PGS). PGS telah dikembangkan untuk upaya mencapai perubahan pola asupan masyarakat dan memiliki tujuan mencapai status gizi masyarakat yang lebih baik. Penerapan PGS ini mengatur jenis makanan dan frekuensi asupan, menghindari junk food dan menjadi salah satu faktor penting dalam upaya preventif dan kuratif anemia gizi zat besi. Pengetahuan dan penerapan PGS dalam mencegah anemia gizi besi sangat diperlukan khususnya bagi wanita usia subur 
mengingat anemia gizi zat besi dapat menyebabkan penurunan kualitas sumber daya manusia (Agustina, 2019).

Selain PGS, terdapat juga Perilaku Hidup Bersih dan Sehat (PHBS). PHBS ialah refleksi akan gaya hidup rumah tangga yang menjaga dan memperhatikan kesehatan anggota keluarganya. Diharapkan dengan pelaksanaan PHBS dalam kehidupan sehari-hari dapat mewujudkan peningkatan derajat kesehatan hidup yang optimal. Masyarakat yang kurang sadar akan pentingnya PHBS dapat menimbulkan masalah pada kesehatan, seperti infeksi reproduksi pada wanita, diare, infeksi saluran kemih, dan kecacingan (Kosasih et al., 2018).

Masyarakat sendiri juga dapat berperan dalam mengatasi permasalahan anemia pada remaja putri. Namun sebelum masyarakat dapat berperan dalam mengatasi anemia pada remaja putri diperlukan pemberian edukasi gizi dan perilaku sehat. Edukasi tentang gizi dan perilaku sehat pada masyarakat bertujuan untuk memberikan pengetahuan kepada masyarakat tentang pola makan sehat. Sehingga masyarakat yang paham dengan manfaat edukasi gizi dan pola hidup sehat maka mereka akan mengadopsi perilaku baru yang baik tersebut. Selain edukasi gizi dan pola hidup sehat kepada masyarakat, edukasi pendidikan kesehatan dapat dilakukan untuk remaja putri. Bentuk edukasi kesehatan tersebut dapat berupa penyuluhan mengenai anemia pada remaja putri.

Berhasilnya edukasi kesehatan tidak terlepas dari keberhasilan media yang digunakan. Media yang bagus dan menarik akan memberikan keyakinan, dan salah satu media yang menarik yaitu video. Video penyuluhan merupakan media audio-visual yang dapat digunakan dalam memberikan edukasi kepada masyarakat luas. Sebagai media, video dapat memberikan informasi yang lebih nyata, dapat diterima secara merata, dapat diulang, atau dihentikan sesuai kebutuhan, yang sangat cocok untuk menjelaskan proses. Pembelajaran dengan menggunakan media video atau audio-visual dapat memberikan hasil keberhasilan yang lebih tinggi dan dapat meningkatkan proses dan hasil pembelajaran (Mawan et al., 2017).

Berdasarkan uraian-uraian di atas, masih terdapat masalah anemia yang belum sepenuhnya teratasi. Upaya dalam meningkatkan generasi muda yang sehat dan bebas dari anemia sangat diperlukan untuk menjadi aset negara. Sehubungan dengan itu, untuk mencegah terjadinya anemia pada remaja putri dilakukan kegiatan untuk mengetahui pengaruh edukasi gizi berbasis video terhadap peningkatan pengetahuan remaja putri berusia 15-21 tahun di wilayah Jakarta Timur. Pada kegiatan ini tidak ada mitra spesifik karena sampel diambil secara insidental. Akan tetapi, kegiatan ini dapat menjadi pendahuluan untuk kegiatan pengabdian kepada masyarakat di masa mendatang dengan mengajak Sekolah Menengah Pertama (SMP) atau Sekolah Menengah Atas (SMA) sebagai mitra agar target menjadi lebih spesifik.

\section{METODE PELAKSANAAN PKM}

Kegiatan ini dilaksanakan pada bulan Oktober 2020. Peserta kegiatan ini adalah remaja putri di wilayah Jakarta Timur sejumlah 74 orang dengan rentang usia 15-21 tahun. Pengambilan data dasar dilakukan secara online melalui grup WhatsApp dan Google Formulir. Edukasi yang diberikan terkait Pedoman Gizi Seimbang (PGS), Perilaku Hidup Bersih dan Sehat (PHBS) dan anemia. Kuesioner yang digunakan berupa kuesioner karakteristik dan kuesioner pengetahuan dalam bentuk pre test dan post test. Materi kuesioner Pre Test dan Post Test dapat dilihat pada Tabel 1. Kuesioner pengetahuan berisi 15 pertanyaan. Media yang digunakan dalam penyampaian edukasi gizi adalah video. Analisis data meliputi analisis univariat dan analisis bivariat. Analisis univariat digunakan untuk melihat distribusi frekuensi usia remaja putri. Analisis bivariat meliputi paired t-test untuk mengetahui perbedaan tingkat pengetahuan mengenai anemia sebelum dan 
sesudah diberikan edukasi. Dokumentasi kegiatan dapat dilihat pada Gambar 1 s.d Gambar 3. Metode pelaksanaan PKM dapat dilihat pada Gambar 4.

\section{Gambar 1}

Screenshot Video Mengenai Pedoman Gizi Seimbang

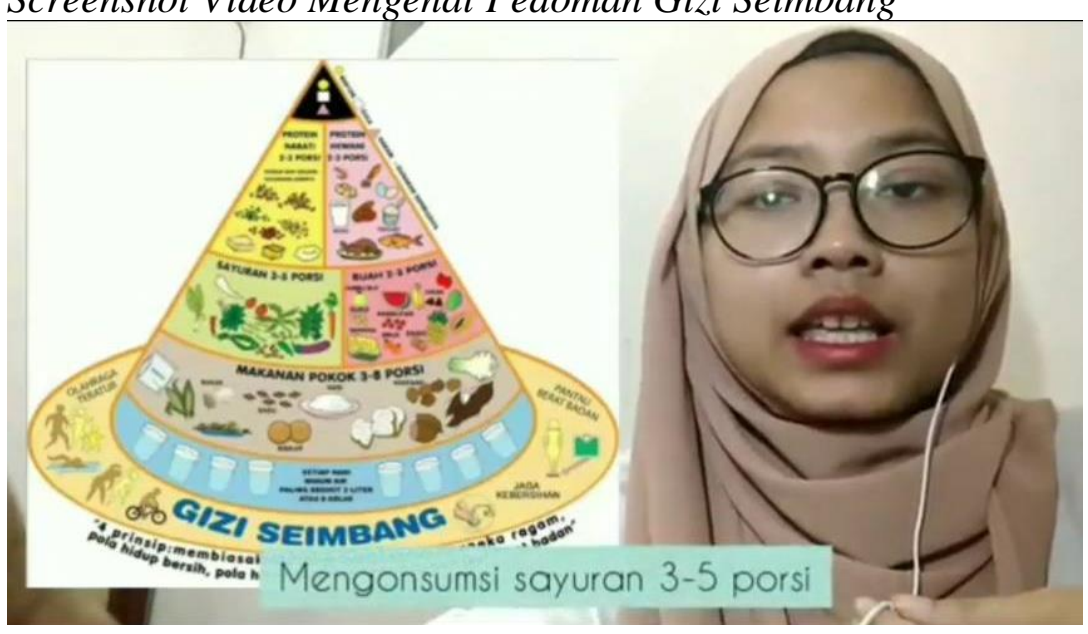

\section{Gambar 2}

Screenshot Video Mengenai Perilaku Hidup Bersih dan Sehat

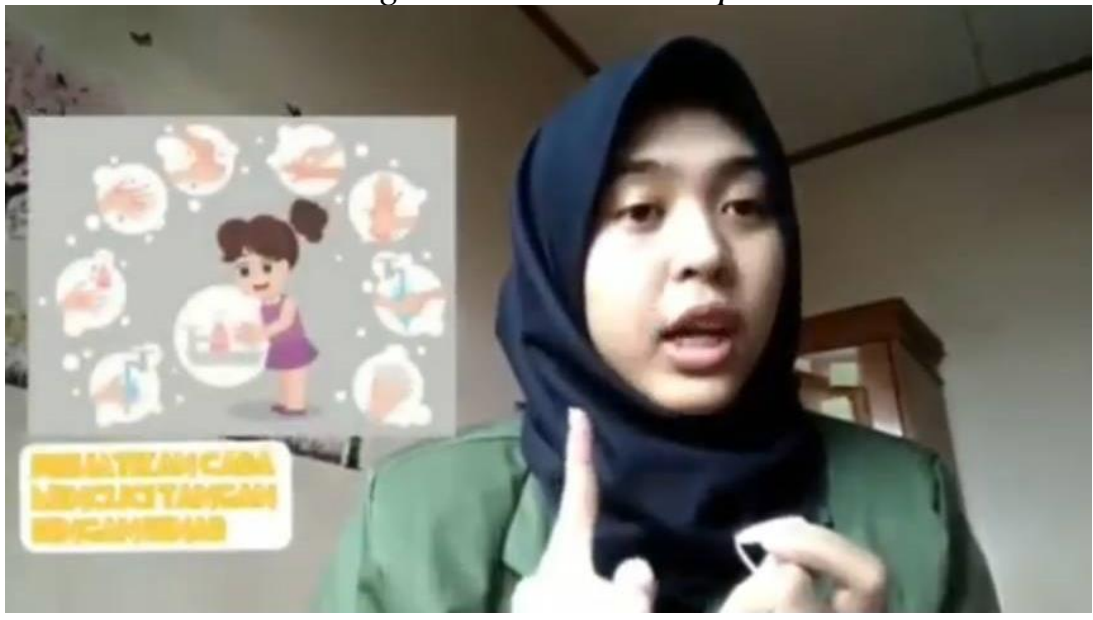

\section{Gambar 3}

Screenshot Video Mengenai Anemia

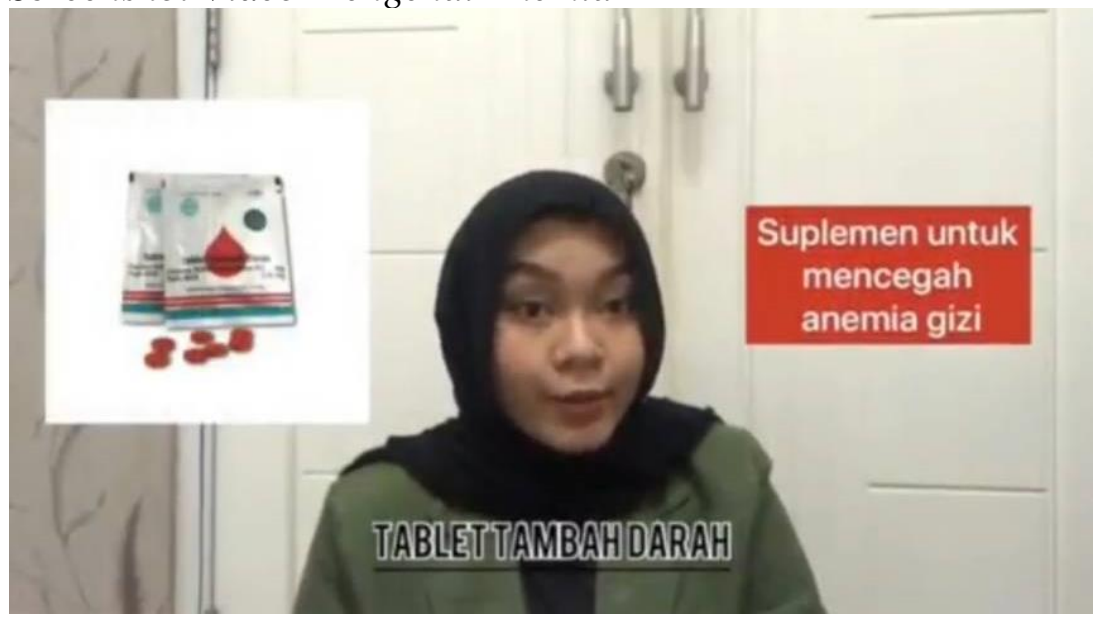




\section{Gambar 4}

\section{Flow Chart Pelaksanaan PKM}

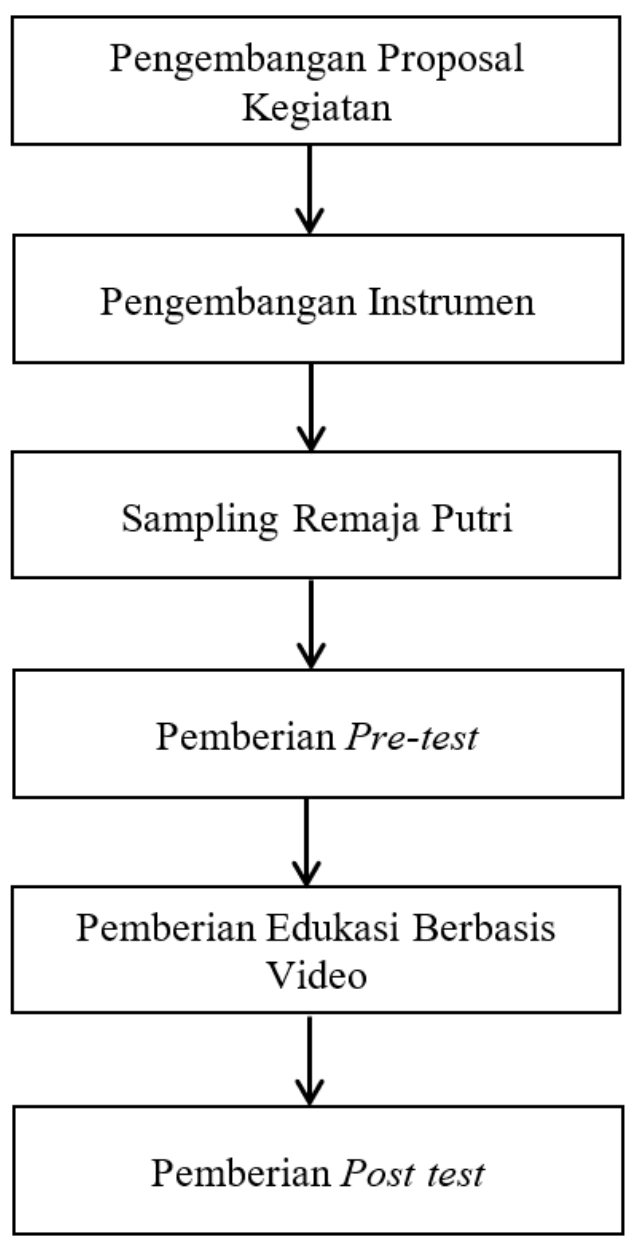

\section{Tabel 1}

Materi Kuesioner Pre Test dan Post Test

\begin{tabular}{cl}
\hline No & \multicolumn{1}{c}{ Materi } \\
\hline 1 & Guideline keseimbangan gizi yang dipakai di Indonesia saat ini \\
2 & Perbedaan pedoman gizi seimbang dengan slogan 4 sehat 5 sempurna \\
3 & Hal yang diperhatikan dalam pedoman gizi seimbang \\
4 & Jumlah isi pesan gizi seimbang \\
5 & Isi pesan gizi seimbang \\
6 & Batas konsumsi garam perhari \\
7 & Anjuran porsi konsumsi makan pokok dalam sehari \\
8 & Kebutuhan asupan air putih dalam sehari \\
9 & Indikator dari perilaku hidup bersih dan sehat \\
10 & Tanda dan gejala anemia \\
11 & Faktor penyebab anemia \\
12 & Hal yang tidak termasuk dalam cara mencegah anemia \\
13 & Hal yang tidak termasuk dalam aturan mengonsumsi tablet tambah darah \\
14 & Sumber makanan yang membantu penyerapan zat besi \\
15 & Alasan anemia dapat memperparah kondisi pasien COVID-19 \\
\hline
\end{tabular}




\section{HASIL DAN PEMBAHASAN}

\section{Analisis Univariat}

Tabel 2

Distribusi Frekuensi Karakteristik Responden

\begin{tabular}{ccc}
\hline Usia (tahun) & $\boldsymbol{N}$ & \% \\
\hline$\leq 18$ & 58 & 78 \\
$>18$ & 16 & 22 \\
Total & 74 & $100 \%$
\end{tabular}

Pada Tabel 2 dapat dilihat hasil distribusi frekuensi usia responden. Usia responden yang berada di bawah atau sama dengan 18 tahun sebanyak 58 orang (78\%) dan yang berada di atas 18 tahun sebanyak 16 orang $(22 \%)$.

\section{Analisis Bivariat}

\section{Tabel 3}

Distribusi Skor Pengetahuan Pedoman Gizi Seimbang (PGS), Perilaku Hidup Bersih dan Sehat (PHBS), Pengetahuan Anemia dan Pencegahannya Sebelum dan Sesudah Pemberian Edukasi

\begin{tabular}{lcccc}
\hline & $\boldsymbol{N}$ & Mean & $\begin{array}{c}\text { Standar } \\
\text { Deviasi }\end{array}$ & P-Value \\
\hline Sebelum & 74 & 8,11 & 2,692 & 0,000 \\
Sesudah & 74 & 12,08 & 2,363 & \\
\hline
\end{tabular}

*Paired T-Test

\section{Gambar 5}

Grafik Rata-Rata Skor Pre Test dan Post Test

Rata-Rata Skor Pre Test dan Post Test

Rata-rata skor pre test dan post test

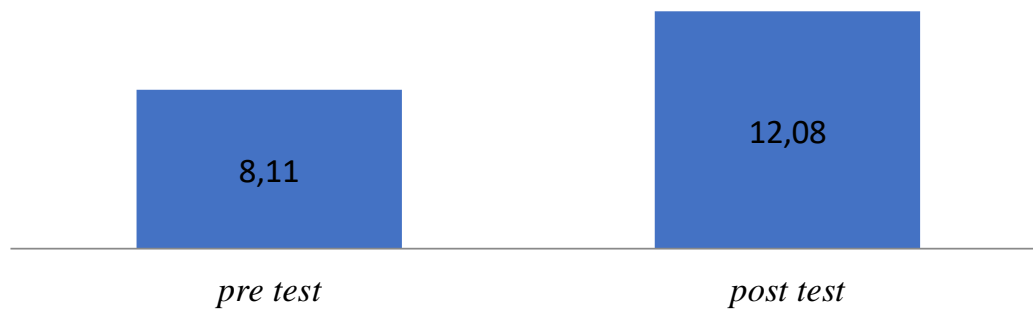

Pada Tabel 3 dan Gambar 5 dapat dilihat hasil analisis skor pengetahuan sebelum dan sesudah diberikan edukasi mengenai Pedoman Gizi Seimbang (PGS), Perilaku Hidup Bersih dan Sehat (PHBS), pengetahuan anemia dan pencegahannya diperoleh rata-rata skor pengetahuan sebelum diberikan edukasi sebesar 8,11 $\pm 2,692$ sedangkan rata-rata skor pengetahuan sesudah diberikan edukasi sebesar $12,08 \pm 2,363$. Analisis skor pengetahun sebelum dan sesudah diberikan edukasi dengan menggunakan paired t-test diperoleh $p$-value sebesar 0,000 (nilai sig. $<\alpha(0,05)$ ) yang berarti Ho ditolak atau H1 diterima. Kesimpulannya ada perbedaan antara skor pengetahuan pre test dan post test setelah diberikan edukasi pada remaja putri berusia 15-21 tahun di wilayah Jakarta Timur. 
Hal ini sejalan dengan penelitian yang telah dilakukan sebelumnya bahwa terdapat perbedaan skor pengetahuan sebelum dan sesudah diberikan edukasi mengenai Pedoman Gizi Seimbang (PGS) berbasis video dengan $p$-value $0,000<0,05$ yang berarti ada pengaruh pemberian edukasi berbasis video terhadap pengetahuan mengenai Pedoman Gizi Seimbang (PGS) (Nirma et al., 2021). Penelitian lain juga menyebutkan bahwa terdapat pengaruh pemberian edukasi dengan media video pada peningkatan pengetahuan mengenai gizi seimbang dengan $p$-value $0,000(\mathrm{pp}<0,05)$ (Ardi \& Sunarti, 2019). Hal ini sejalan dengan penelitian yang telah dilakukan sebelumnya bahwa terdapat perbedaan skor pengetahuan sebelum dan sesudah diberikan edukasi mengenai gizi seimbang berbasis video dengan $p$-value 0,000 $<0,05$ yang berarti ada pengaruh pemberian edukasi berbasis video terhadap pengetahuan mengenai gizi seimbang dan media video dinilai efektif dalam kegiatan edukasi gizi seimbang untuk meningkatkan pengetahuan pada remaja (Utami, 2018).

Hal ini sejalan dengan penelitian lain edukasi gizi berbasis video terhadap pengetahuan mengenai Perilaku Hidup Bersih dan Sehat (PHBS) dengan rata-rata nilai skor pre test sebesar 61,33, sedangkan skor post test sebesar 89,10 dan p-value 0,000 $<0,05$ yang berarti ada pengaruh pemberian edukasi berbasis video terhadap pengetahuan mengenai Perilaku Hidup Bersih dan Sehat (PHBS) (Mawan et al., 2017). Penelitian lain juga menyebutkan bahwa terdapat pengaruh pemberian edukasi media video pada peningkatan pengetahuan mengenai Perilaku Hidup Bersih dan Sehat (PHBS), dengan skor rata-rata pengetahuan sebelum pemberian edukasi sebesar 7,01 \pm 0,93 dan skor rata-rata pengetahuan setelah pemberian edukasi sebesar 9,48 $\pm 0,46$. Hal tersebut juga didukung dengan $p$-value sebesar $0,000(\mathrm{p}<0,05)$ (Rusdiyana, 2019). Hal ini juga sejalan dengan penelitian sebelumnya yang menyatakan bahwa terdapat perbedaan skor pengetahuan mengenai Perilaku Hidup Bersih dan Sehat (PHBS) antara sebelum dengan sesudah diberikan edukasi dengan video, hal tersebut didukung dengan $p$-value sebesar $0,000(\mathrm{p}<0,05)($ Festy, 2015).

Hal ini juga sejalan dengan penelitian sebelumnya tentang edukasi gizi pengetahuan anemia berbasis video, didapatkan skor rata-rata pengetahuan remaja putri sebelum intervensi sebesar $52.00 \pm 9.24$, setelah diberikan intervensi, skor rata-rata pengetahuan remaja putri meningkat menjadi $83.60 \pm$ 5.11. Secara statistik, didapatkan p-value sebesar 0.000 ( $\mathrm{p}<0.05)$ yang menunjukkan adanya perbedaan yang signifikan pada pengetahuan remaja putri antara sebelum dengan sesudah diberikan pengetahuan tentang anemia (Hatini, 2021). Penelitian sebelumnya juga menyimpulkan hal yang serupa, didapatkan skor rata-rata pengetahuan remaja putri sebelum diberikan edukasi sebesar 5,1 $\pm 1,62$, setelah diberikan edukasi, skor rata-rata pengetahuan remaja putri meningkat menjadi $8,71 \pm 1,64$. Hal tersebut dibuktikan juga dengan $p$-value $<0,05$ yang berarti terdapat perbedaan yang signifikan pada pengetahuan remaja putri antara sebelum dengan sesudah diberikan edukasi mengenai anemia berbasis video (Fitriani et al., 2019). Hal ini sejalan dengan penelitian sebelumnya, yaitu ada perbedaan rata-rata skor pengetahuan sebelum dan sesudah diberikan edukasi mengenai anemia yang semula sebesar 69,88 menjadi sebesar 77,70 yang artinya ada pengaruh edukasi berbasis video animasi terhadap pengetahuan subjek $(\mathrm{p}<0,05)$ (Syakir, 2018).

Pengetahuan merupakan faktor yang sangat penting dalam pembentukan perilaku baru. Dimulai dengan pemahaman terhadap materi atau objek tertentu. Salah satu upaya untuk meningkatkan pengetahuan dengan memberikan pendidikan atau kegiatan konsultasi terkait gizi, khususnya pengetahuan terkait gizi. Edukasi tidak dapat dipisahkan dari media, karena melalui media informasi dapat dengan mudah dikomunikasikan dan dipahami. Media yang digunakan dapat memperjelas informasi, menghindari kesalahpahaman, dan membantu pemahaman. 
Media yang digunakan dapat memperjelas informasi, menghindari kesalahan persepsi, dan juga mempermudah pengertian. Media promosi kesehatan merupakan sarana promosi kesehatan, sehingga sasaran dapat memahami informasi kesehatan, serta membantu menentukan perilaku hidup sehat berdasarkan informasi yang disampaikan (Fitriani et al., 2019). Media penyuluhan kesehatan merupakan alat bantu penyuluhan yang mana alat-alat ini akan digunakan oleh penyuluh dalam menyampaikan edukasi. Setiap alat memiliki kekuatan yang berbeda dalam membantu persepsi atau gaya berpikir seseorang (Asyary et al., 2018). Jenis media yang dapat digunakan dalam penyuluhan atau edukasi kesehatan salah satunya ialah video.

Video merupakan jenis media audio-visual menggambarkan objek yang bergerak dengan suara alami atau suara yang sesuai. Sebagai media, video dapat memberikan informasi yang lebih nyata, dapat diterima secara merata, dapat diulang, atau dihentikan sesuai kebutuhan, yang sangat cocok untuk menjelaskan proses (Mawan et al., 2017). Dalam video dituangkan kontenkonten untuk memberikan informasi, menjelaskan konsep, memaparkan proses, mengajarkan keterampilan, dan juga berperan sebagai media yang memengaruhi pengetahuan dan sikap (Fahri, 2020).

\section{KESIMPULAN DAN SARAN}

Hasil kegiatan ini menunjukkan bahwa terdapat perbedaan rata-rata skor pengetahuan antara sebelum diberikan edukasi dengan sesudah diberikan edukasi yang berarti ada pengaruh edukasi gizi berbasis video terhadap tingkat pengetahuan mengenai Pedoman Gizi Seimbang (PGS), Perilaku Hidup Bersih dan Sehat (PHBS), serta pengetahuan anemia dan pencegahannya pada remaja putri berusia 15-21 tahun di wilayah Jakarta Timur dengan $p$-value $<0,05$.

\section{Ucapan Terima Kasih (Acknowledgement)}

Kami ucapkanterima kasih kepada dekanat Fakultas Ilmu Kesehatan Universitas Pembangunan Nasional Veteran Jakarta yang telah mengizinkan terselenggaranya kegiatan ini, panitia kegiatan Gizi Bakti Masyarakat, para remaja putri di Jakarta Timur yang sudah berpartisipasi dalam kegiatan ini, para donatur dan seluruh partisipan dalam kegiatan ini.

\section{REFERENSI}

Agustina, P. P. (2019). Hubungan Pengetahuan dan Penerapan Pesan Gizi Seimbang pada Remaja dalam Pencegahan Anemia Gizi Besi. Jurnal Ilmiah Kesehatan Masyarakat, 11(11), 1-9.

Apriyanti, F. (2019). Hubungan Status Gizi Dengan Kejadian Anemia Pada Remaja Putri Sman 1 Pangkalan Kerinci Kabupaten Pelalawan Tahun 2019. Jurnal Doppler Universitas Pahlawan Tuanku Tambusai, 3(2), 18-21.

Ardi, H. F., \& Sunarti, S. (2019). Pengaruh media video terhadap pengetahuan dan sikap tentang gizi seimbang pada siswa kelas V di SDN 016 Samarinda Seberang. Jurnal Borneo Student Research, 284-290.

Asyary, M. S., Moviana, Y., \& Surmita. (2018). Penyuluhan Gizi dengan Pengembangan Food Model'Piring Makanku' Meningkatkan Perilaku Konsumsi Makanan Seimbang pada Remaja. Jurnal Riset Kesehatan Poltekkes Depkes RI Bandung, 10(1), 1-8. https://juriskes.com/ojs/index.php/jrk/issue/archive\%0Adiakses pada tanggal 06 mei 2020

Badan Penelitian dan Pengembangan Kesehatan. (2018). Laporan_Nasional_Rkd2018_Final.pdf. In Badan Penelitian dan Pengembangan Kesehatan (p. 198).

Fahri, A. D. (2020). Pengaruh Edukasi Melalui Media Video dan Teks pada Grup Whatsapp Terhadap Pengetahuan dan Sikap Ibu Tentang ASI di Kota Medan.

Festy, M. P. (2015). Pengaruh imaginative pretend play dengan media video animasi: Pengetahuan dan sikap perilaku hidup bersih dan sehat. The Sun, 2(1), 38-46. 
Fitriani, D. S., Eko, G. P., \& Dkk. (2019). Penyuluhan Anemia Gizi Dengan Media Motion Video Terhadap Pengetahuan Dan Sikap Remaja Putri. Jurnal Kesehatan, 97-104.

Harahap, N. R. (2018). Faktor- Faktor Yang Berhubungan Dengan Kejadian Anemia Pada Remaja Putri. Nursing Arts, 12(2), 78-90. https://doi.org/10.36741/jna.v12i2.78

Hatini, E. E. (2021). Pemanfaatan Video Youtube Tentang Anemia Pada Remaja Putri Di Smk Yp Sei Palangka Raya Utilization Of Youtube Video About Anemia On Adolescent Girls In Smk Yp Sei Palangka Raya. Jurnal Surya Medika (JSM), Vol. 6(No. 2), 53-60.

Indrastata, N. N. (2019). Analisis Penyebab Anemia pada Wanita Menstruasi Mahasiswi Pascasarjana UNS. 2017. https://doi.org/10.31227/osf.io/fskht

Junengsih, J. J., \& Yuliasari, Y. Y. (2017). Hubungan Asupan Zat Besi Dengan Kejadian Anemia Pada Remaja Putri Smu 98 Di Jakarta Timur. Jurnal Ilmu Dan Teknologi Kesehatan, 5(1), 55-65. https://doi.org/10.32668/jitek.v5i1.68

Kosasih, C. E., Solehati, T., \& Rahmat, A. (2018). Gambaran Sumber Informasi Phbs Pada Kader Kesehatan. PROMOTIF: Jurnal Kesehatan Masyarakat, $8(1), \quad 56$. https://doi.org/10.31934/promotif.v8i1.230

Mawan, A. R., Indriwati, S. E., \& Suhadi. (2017). Pengembangan Video Penyuluhan Perilaku. Jurnal Pendidikan: Teori, Penelitian, Dan Pengembangan, 2(7), 883-888.

Nirma, A., Zares, M., \& Simanungkalit, S. F. (2021). Effect of Nutrition Education Based on Video and Leaflet Towards Nutritional Knowledge of 14 th Junior High School Bekasi Student. Indonesian Journal of Nutritional Science, 01(1), 8-15. https://ejournal.upnvj.ac.id/index.php/IJNS/article/view/2519

Nurramadhani, S.R., Fillah Fithra Dieny, Etisa Adi Murbawani, A Fahmy Arif Tsani, Deny Yudi Fitranti, N. W. (2019). Status Besi dan Kualitas Diet berdasarkan Status Obesitas pada Wanita Usia Subur di Kota Semarang. Amerta Nutrition, 3(4), 247-256. https://doi.org/10.20473/amnt.v3i4.2019.247-256

Rusdiyana. (2019). Pengaruh Edukasi Terhadap Pengetahuan Perilaku Hidup Bersih dan Sehat (PHBS) Siswa Kelas V SDN Cindai Alus 1 Kabupaten Banjar. Volume, Jurnal Wahana-Bio Juni, X X I, XXI, 1-9.

Sukarni \& Wahyu, 2013. (2013). Pemberian Zat Besi (Fe) Dalam Kehamilan Oleh: Is Susiloningtyas. Majalah Ilmiah Sultan Agung, 50(128). http://lppmunissula.com/jurnal.unissula.ac.id/index.php/majalahilmiahsultanagung/article/view/74

Syakir, S. (2018). Influence of nutrition education using animation media on knowledge and attitude about anemia of adolescence girls. ARGIPA (Arsip Gizi Dan Pangan), 3(1), 18-25.

World Health Organization. (2011). Prevention of iron deficiency anaemia in adolescents. Role of Weekly Iron and Folic Acid Suplementation, 50 